\title{
ЕМОЦЙНА СЕМАНТИКА ПАРАЛІНГВАЛЬНИХ ФРАЗЕМ НА ПОЗНАЧЕННЯ НЕГАТИВНИХ ПСИХІЧНИХ СТАНІВ МОВЦЯ
}

\footnotetext{
Демиденко Г. Г. Емоційна семантика паралінгвальних фразем на позначення негативних психічних станів мовця.

У статті з'ясовано особливості мовної репрезентації психічного стану «відчай»; визначено специфіку фразеологічних одиниць із невербальним компонентом у ролі семантичного індикатора, тим самим указано місце таких сталих висловів у системі засобів, які формують емоційний код мови.

Ключові слова: емоція, емоційна семантика, психічний стан, паралінгвальний фразеологізм.
}

Демиденко А.Г. Эмоциональная семантика паралингвистических фразем, обозначающих негативные психические состояния говорящего.

Статья рассматривает особенности языковой репрезентации психического состояния «отчаяние»; определена специфика фразеологических единиц с невербальним компонентом в роли семантического индикатора, тем самым указано место таких устойчивых выражений в системе тех средств, которые формируют эмоциональный код языка.

Ключевые слова: эмоция, эмоциональная семантика, психическое состояние, паралингвистический фразеологизм.

Demidenko A. G. Emotional semantics paralinguistical phraseologism, designating negative mental conditions of speaker.

The article defines features of language репрезентации a mental condition «despair»; explains specificity of phraseological units with nonverbal component in a role of the semantic indicator is defined, the place of such steady expressions in system of those means which form an emotional code of language.

Key words: emotion, emotional semantics, a mental condition, paralinguistical phraseologism.

Емоційна сфера комунікації являє собою важливий аспект у розв'язані основних питань сучасної лінгвістики, зокрема мови та мислення, мови і свідомості, індивідуального й колективного в мові тощо. Посилення інтересу до вивчення лінгвістики емоцій - емотиології - засвідчено появою низки робіт вітчизняних i зарубіжних учених (Ю. Д. Апресян, Н. Д. Арутюнова, А. Вежбицька, Т. Р. Звєрева, А. М. Манзій, Н. В. Лугова, П. О. Селігей, О. В. Урисон, Н. А. Хом'якова, В. І. Шаховський), що і визначило значущість цього напрямку наукових пошуків.

У процесі аналізу різних тематичних пластів фразеології української мови виявлена особлива здатність деяких з них називати емоції, почуття, 
емоційні стани особи. Паралінгвальні стійкі звороти постають у комунікативному просторі окремого етносу як результат узаємодії семіотичних систем - вербальної та невербальної. 3 огляду на те, що будьяка емоційна реакція спричиняє зміни людського організму (фізіологічні, на рівні глибинних структур психіки і т. ін.), невербальну поведінку можна зарахувати до важливих складових емоційного світу мовця.

Мета наукової розвідки полягає у вивченні особливостей семантичної структури фразем на позначення паравербальних дій зі значенням розпачу, відчаю i, як наслідок, апатійного стану в українському мовному середовищі.

У сучасній психології під емоційними станами розуміють такі психічні стани, які виникають у процесі життєдіяльності суб'єкта і визначають не тільки рівень інформаційно-енергетичного обміну, але i спрямованість поведінки. До них належать: 1) радість (задоволення, веселощі); 2) смуток (апатія, сум, депресія); 3) гнів (агресія, озлоблення); 4) страх (тривога, переляк); 5) подив (цікавість); 6) огида (презирство).

До емоційних станів зараховують: настрої (загальне емоційне тло), афекти (інтенсивні реакції на екстремальні умови, коли індивід втрачає здатність до саморегуляції), стреси (реакції на недостатність задоволення життєво важливих потреб, що потребують мобілізації всіх зусиль), фрустрації (реакції на ситуації перешкоди, які виявляються в тимчасових порушеннях зв'язку між свідомістю і діяльністю).

Відомо, афектні прояви позитивних емоцій - захоплення, натхнення, ентузіазм, напад нестримних веселощів, сміху, прояви негативних емоцій це лють, гнів, жах, відчай, що нерідко супроводжуються ступором (застиганням у нерухомій позі). Після афекту часто спостерігається занепад сил, байдужість до всього або розкаяння у скоєному злочині (афектний шок). Часті прояви афекту у звичайній ситуації спілкування свідчать про невихованість людини (вона дозволяє собі входити в афектний стан) або про наявність нервово-психічного захворювання.

Згідно з класифікацією Ю.Ф. Прадіда, тематичне поле ФО «емоційні процеси людини» нараховує тринадцять груп, а саме: 1) відраза, огида; 2) задоволення, радість; 3) гнів, лють; 4) захват, захоплення; 5) любов, пристрасть; 6) страждання, мука; 7) занепокоєння, тривога; 8) здивування, подив; 9) зневага, нехтування; 10) збентеження сором; 11) страх, жах; 12) сум, печаль; 13) відчай, приреченість [6, с. 97]. Семантична структура стійких виразів на позначення емоційної модальності розгалужена й може засвідчувати емотиви-номінанти жестів, мімічних дій, фонаційних реалій спілкування. 3 позиції психологічної науки «відчай - це психічний стан розпачу, безперспективності (дійсних чи уявних), зневіри людини у своїх можливостях, втрата позитивних надій щодо сучасного і майбутнього; він може виникати на грунті невиліковних хвороб, глибоких розладів нервової системи і психіки, а також збігу надто несприятливих для людини 
зовнішніх обставин» [2, с. 29]. Такі обставини мають різну природу, однак усі вони неодмінно створюють для індивіда враження про його приреченість перед майбутньою загрозою. Логічно напрошується висновок: довести людину до відчаю може жах своїм крайнім виявом. Певне страхіття охолоджую кров, провокує заціпеніння тіла i повне безсиллям, втрату голосу. Однак психологічна відмінність між цими поняттями наявна і полягає в тому, що вони обидва характеризують повну безнадійність. Інша річ, чи призведе ця безнадійність до жаху або відчаю, залежить від того, як людина сприймає майбутнє нещастя. Якщо вона вимірює його величину, то відчуває розпач, якщо - наближення, то нею керує жах. В обох випадках вона страждає, але від різних причин: у відчаї - від самого нещастя, у жахові - від неминучості наближення. Сила відчаю корелює зі зниженням потенційної сили людини, яка чинить опір нещастю, а також з неминучістю лиха. Жах, зі свого боку, визначається величиною майбутньої небезпеки.

Мовний аспект вивчення емоційної семантики дещо відрізняється від психологічної підоснови, адже «у психологічній науці розрізняють чуттєвий тон, емоцію, афект, почуття, пристрасть і настрій, у мові ж поняття «емоція» та «почуття» не розмежовується. Емоції виступають складовими почуттів, настрій характеризується значною тривалістю певних емоцій (останній може «закорінюватися» в певному емоційному стані - Г. Д.)», тому «ці лексеми протиставляються за диференційним семами «ступінь участі мисленнєвого компонента», «об'єкт», «часова тривалість» [1, с. 124]. Це твердження справедливе і для паралінгвальних фразем з емоційною семантикою за умови, що невербальна ii складова відповідає наведеним диференційним семам. Зауважимо: часові межі переживання емоційної реакції та відповідної паравербальної дії не завжди збігаються і зумовлюють одне одного. Так, людина може перебувати, скажімо, у відповідному стані, однак не сигналізувати про це візуально.

Проілюструємо нашу думку мовним матеріалом, який складають сталі вислови на позначення стану відчаю, розпачу, апатійності: битися (бити [себе]) об поли [руками] [8, с. 30]; битися головою об стіни [8, с. 30]; вбирати (втягувати) / ввібрати (втягти, втягнути) голову в плечі $[8$, с. 54]; аж за голову взятися [8, с. 61]; вити вовком (звіром) [8, с. 88]; вішати / повісити голову [8, с. 114]; вішати (хнюпити, опускати) / повісити (похнюпити, опустити) носа (ніс) [8, с. 114]; махнути / рідше махати рукою [8, с. 382]; кисла міна [8, с. 391]; опустити / опускати вуха [8, с. 468]; опустити / опускати голову [8, с. 468]; [аж] рвати (дерти, скубти і т. ін.) на собі (на голові) волосся (чуба) [8, с. 594]; руки опускаються /опустилися [8, с. 624]; спадати / спасти з лиия (на лиџі, на виду) [8, с.678]; [аж) ударити об поли руками [8, с. 732]; як у воду опущений [8, с. 468]. Серед наведених одиниць найбільшу частину становлять жестові фразеологізми, менше - мімічні символічні рухи. 
Вислів ажс за голову взятися «уживається для вираження сильного здивування, переживання, туги, розпачу тощо» і репрезентує відповідно стан безвихідності мовця. «Жестикулянт береться за голову обома руками, переважно за потилицю чи бокову частину так, аби вся поверхня долонь охоплювала іiі. Цей жест мотивовано фізичним рухом, який людина виконує у момент головного болю, прагнучи полегшення» [3, с. 137]. Відповідно ФО використовуватиметься в ситуації, коли особа дізнається деяку несподівану для себе інформацію в якійсь ситуації, до якої вона може бути певним чином причетна. Інші обставини комунікації: відбувається усвідомлення власної неправильної дії або вчинку. Експресія жестового деривата передається за певних умов узаємодії і стійкому звороту, створюючи додаткові прагматичні відтінки, коли підкреслюється деяка театральність комунікативного процесу, зокрема поведінки індивіда.

Фразеологізм опустити / опускати вуха означає «впасти у відчай, засмутитися, зневіритися i т. ін.». Не викликає сумніву те, що мотивованість цієї одиниці пов'язана з метафоричним переосмисленням відповідного тваринного руху органами слуху внаслідок особливостей їх анатомічної будови. Перебуваючи у пригніченому стані, тварина опускає голову, вуха, присідає нижче до землі, починає плазувати. Людина не в змозі переживати цю емоцію на фізичному рівні, буквально опускаючи вуха, проте вона відчуває свою приреченість у ситуації, пов'язаної із задоволенням потреби, потягом, з досягненням задуманого та бажаного.

Характерний для стану зневіри i такий сталий зворот вбирати (втягувати) / ввібрати (втягти, втягнути) голову в плечі, який тлумачиться як «знітитися від чого-небудь (від страху, сорому тощо)». Зовнішній вигляд людини передає «емоційний тон» їі внутрішнього стану: рухи повільні, руки та голова опущені. Безперспективність розв'язання якогось питання, усвідомлювана безнадія викликає в мовця не лише відповідні рухи голову вниз, але й піднімання плечей угору. Так проявляється закономірна захисна реакція особистості, бажання «прихистити себе у своєму ж тілі».

Семантика вислову руки опускаються / опустилися, а саме «хтонебудь впадає в апатію, стає байдужим, пасивним, бездіяльним; не хоче робити чогось» доповнює попередній приклад. У словнику жестів представлено таку одиницю опускати / опустити руки (плечі), що використовується задля «вираження пасивності, безвольності, пригнічення у зв’язку 3 нещастям, горем» [1, с. 89]. Однак наголосимо на психологічній різниці між відчаєм та апатією, яка полягає в інтенсивності та тривалості явища «душевної розпуки». Фразема демонструє позу людини, плечі якої розслаблені (вона вже не спроможна на продукування захисних стратегій), низько опущені, руки звисають уздовж тіла або лежать на колінах, голова також опущена.

Деяка невідповідність семантики жестового фразеологізму й відповідного жесту засвідчена відповідно в таких одиницях махнути / рідше махати рукою, що вживається на позначення «1) перестати займатися ким-, 
чим-небудь, турбуватися про когось, щось, збайдужіти до когось, чогось // Перестати говорити про щось, обірвати розмову // Залишити, покинути когось, щось. 2) не турбувати, не чіпати когось // Відмовитися від кого-, чогонебудь. Перестати сподіватися на щось, чекати чогось // Утратити віру; зневіритися // Примиритися з чимось; заспокоїтися»; і махати / махнути, замахати рукою (руками) зі значеннями «1) відмова від контакту, розмови, висловлення думки; 2) незадоволення, почуття прикрості, роздратованості; негативні оцінка чогось; 3) вираження безвиходi, безперспективності становища (курсив наш - Г. Д.)» [1, с. 86-87]. Первісне значення символічної дії асимілювалося у вислові, де відображено лише елемент безпорадності людини в певній комунікативній ситуації - збайдужіння до когось або чогось. Видозмінених прагматичних потенцій набувають вербалізовані жести, які вирізняються полісемією, тоді частина значень утрачаються, частина трансформуються відповідно до процесів концептуалізації емоційної сфери життя народу.

Яскраве проживання емоції відчаю фіксує й інший стійкий вираз битися головою об стіни - «перебуваючи у стані розпачу, даремно докладати зусилля, щоб запобігти чомусь небажаному». Напевне, жестовий еквівалент такого потужного фізичного руху має стосунок до переживання розпачу на межі 3 досадою. Остання, як відомо, може спровокувати насильницькі дії як на адресу учасників комунікації, так і особистісно зорієнтовані. Це так звана «емоційна розрядка», здатна знизити дію негативного емоційного фону для людини.

Фразеологізм [ажс] рвати (дерти, скубти і т. ін.) на собі (на голові) волосся (чуба), який означає «впадати у великий відчай, розпач; дуже переживати, побиватися» зосереджує увагу мовця на інтенсивності виконуваної дії. Виймати волосся з голови з величезною силою, на нашу думку, має ознаки специфічного психічного розладу, що набуло переосмисленого значення. Проблема висмикування пасом волосся виникає в дитячому віці. Такі можливі маніпуляції з власним волоссям мають виразно ритуальний характер, звичайно пов'язаний зі символічним захистом від передбачуваної шкоди. Психічні стереотипи реалізовуються іншими симптоматичними проявами. Подекуди цей розлад $\epsilon$ способом самозаспокоєння на тлі психічної напруги, конфліктних ситуацій мозок «пригадує» про «ефективний спосіб» самоунормування, i звичайне накручування волосся трансформувалося у психічне захворювання. Клінічна картина може мати такий вигляд: прагнення здійснити самопокарання, істинне або демонстративне. Людина нелогічно завищує або занижує свою самооцінку, що залежить від природжених психологічних особливостей і впливу соціуму. Проте в обох випадках, якщо очікування та вимоги особистісно важливих людей не виправдовуються, виникає психологічна декомпенсація. При заниженій самооцінці - самопокарання здебільшого істинне, при завищеній самооцінці - демонстративне. 
Виривання волосся може свідчити про повну покірність долі, про неможливість відповідати вимогам ззовні чи бути способом привернення уваги до себе. А відтак, вислів досить чітко формулює особливості несприятливої ситуації спілкування, у якій мовець прагне метафорично компенсувати емоційне навантаження фізичним упливом саморуйнівного характеру.

Окремі положення, висловлені в науковій праці, можуть закликати до дискусії, адже встановити мотивованість того чи того жесту, i, відповідно, через нього фразеологізму, буває вкрай важко, що створює певну неоднозначність витлумачення таких сталих зворотів. Цим забезпечується актуальність дослідження та перспективність подальших пошуків, передусім це стосується висловів, зв’язок яких 3 жестовим дериватом утрачено й у разі, коли самі жестові одиниці не зафіксовані спеціальними словниками.

\section{1. Акишина А А Жесты и мимика Література} А. А. Акишина, Х. Кано, Т. Е. Акишина. - М. : Русский язык, 1991. - 146 с.

2. Григоренко Н. Проблеми визначення мовних одиниць на позначення емоцій (на матеріалі української та англійської мов) / Н. Григоренко // Наукові записки. - Вип. 89 (3). - Серія : філологічні науки (мовознавство) : у 5 ч. - Кіровоград : РВВ КДПУ ім. В. Винниченка, 2010. - С. 123-127.

3. Григорьева С. А. Словарь языка русских жестов / Григорьева С. А., Григорьев Н. В., Крейдлин Г. Е. - Москва-Вена : Языки русской культуры; Венский славистический альманах, 2001. - 256 с.

4. Зверева Т. Р. Эмоции во фразеологической картине мира русского языка с позиции носителя удмуртского языка : автореф. дис. на соискание ученой степени канд. филол. наук 10.02 .01 «Русский язык» / Т. Р. Зверева. - М., 2002. - 20 с.

5. Манзій А. М. Емоційна лексика у сучасній німецькій мові : структура, семантика : автореф. дис. на здобуття наук. ступеня канд. філол. наук 10.02.04 «Германські мови» / А. М. Манзій. - Чернівці, 2008. - 19 с.

6. Прадид Ю. Ф. Русско-украинский и украинско-русский тематический словарь. Эмоции человека. Симферополь, 1994. - 244 с.

7. Психологічний словник / За ред. В. І. Войтка. - К. : Вища школа, 1982. - 216 с.

8. Словник фразеологізмів української мови [уклад. В. М. Білоноженко та ін.]. - К. : Наукова думка, 2003. $-1104 \mathrm{c}$.

9. Хомякова Н. А. Эмотивные фразеологизмы в русском, французском и английском языках (сопоставительный анализ) : автореф. дис. на соискание научн. степени канд. филол. наук 10.02 .20 «Сравнительноисторическое, типологическое и сопоставительное языкознание» / Н. А. Хомякова. - М., 2008. -23 с.

Стаття надійшла до редакції 20.10.2011 p. 